\title{
Small Intestinal Epithelial Brush Border Enzymatic Changes in Suckling Mice Infected with Reovirus Type 3
}

\author{
DAVID BRANSKI, M.D.. EMANUEL LEBENTHAL. M.D.." ${ }^{\prime * \prime}$ HOWARI FADEN, M.D.. TERRY F. \\ HATCH. M.D., AND JOSEPH KRASNER, Ph.D. \\ Division of Gastroenterology and Nutrition. Department of Pediatrics, School of Medicine, and The Children's \\ Hospital of Buffalo, Buffalo, New' York, USA
}

\section{Summary}

Suckling mice infected with reovirus type 3 were examined for changes in the epithelial brush border of the small intestine. After 3 days of infection with reovirus type 3 , no significant changes were found in intestinal morphology or activity of any enzymes tested. After 6 days, villi were shortened and blunted with lymphangiectatic lesions and mild mononuclear infiltration in the lamina propria. In addition, there was a significant decrease in lactase $(P<0.001)$ and enterokinase activity $(P<0.05)$. However, there were no significant changes in the activities of alkaline phosphatase. In contrast, maltase $(P<0.001)$ and leucine aminopeptidase $(P<0.05)$ activities in the infected mice were significantly increased. These data suggest that brush border enzymes are affected differently by reovirus infection.

\section{Speculation}

The decrease in lactase activity and increase in maltase and leucine aminopeptidase in infant mice infected with reovirus type 3 can be a reflection of accelerated maturation subsequent to an increased turnover of the epithelial cells of the crypt and villi or to an induction of specific enzymes. In addition, it is possible that the severe decrease of lactase activity in comparison to other brush border enzyme changes is due to the fact that lactase is more vulnerable than are other enzymes to mucosal injury and the possibility that lactase is a receptor for the virus.

Rotavirus has been identified as the major cause of viral gastroenteritis in children (15). Although the mechanism of diarrhea is not well understood, clinical specimens from small bowel biopsies have demonstrated flattened villi and diminished levels of disaccharidases $(3,9,13)$. Difficulty in growing rotavirus in tissue culture has hampered laboratory investigation of the pathogenesis of rotavirus diarrhea. In the present study, we infected suckling and adult mice with reovirus type 3 , a virus morphologically similar to rotavirus, as a model of viral infection to investigate changes in intestinal morphology and brush border enzymes (7).

\section{MATERIALS AND METHODS}

Twenty-four nine-day-old suckling mice and eight adult mice were given injections IP with $1 \times 10^{7}$ plaque-forming units ( $P F U$ ) of reovirus type 3 . The mice were sacrificed 3 or 6 days after viral inoculation. The control groups consisted of eighteen suckling mice matched for age and given injections of saline while a group of adult mice treated in the same manner served as an ageresponse control. The newborn mice were suckling while the adult mice were maintained on a standard Purina chow diet with food and tap water ad libitum.

At 3 or 6 days postviral infection, the mice were sacrificed by cervical dislocation. The jejunum was excised and divided into 3 parts. The proximal part was stored immediately in $-20^{\circ} \mathrm{C}$ for enzymatic assays. The second part was put in $10 \%$ formalin solution for histology, and the third section was stored in $-60^{\circ} \mathrm{C}$ for virologic study. The mucosa from the proximal part was weighed, diluted with ice-cold water $(0.05 \mathrm{ml} / \mathrm{mg}$ of mucosa), and homogenized in a Potter-Elvehjem glass homogenizer with a Teflon plunger. The homogenate was used for enzyme determinations.

Alkaline phosphatase (EC 3.1.3.1) was determined by the hydrolysis of $p$-nitrophenylphosphate to $p$-nitrophenol and phosphate. In alkaline media, the increase in absorbance at $400 \mathrm{~nm}$ is due to the presence of $p$-nitrophenol (2). Units are expressed as $\mu \mathrm{moles} / \mathrm{min} / \mathrm{g}$ of protein.

Enterokinase (EC 3.4.21.9) was determined by a modification of Hadorn's method (5) which was based on the method as established by Kunitz. The rate of trypsinogen conversion to trypsin was dependent on enterokinase. The rate of trypsin formation was measured from the hydrolysis of the substrate benzoylDI-arginine $p$-nitroanilide. Units are reported as $\mu$ moles $/ 30 \mathrm{~min}$ / $30 \mathrm{~g}$ of protein $(5)$.

Leucine aminopeptidase (EC 3.4.1.1) activity was determined from the hydrolysis of the substrate 1 -leucine- $p$-nitroanilide to $\mathrm{L}$ leucine and $p$-nitroaniline by the homogenate. Activity was determined by the rate of $p$-nitroaniline formation as measured by the $405 \mathrm{~nm}$ absorbance. Enzyme activity is expressed as nmoles of product per min per $g$ of protein at $25^{\circ} \mathrm{C}(14)$.

The disaccharidase, lactase (EC 3.2.1.23), and maltase (EC 3.2.1.20) were determined by incubating the intestinal homogenate with the appropriate substrate in a maleate buffer, $\mathrm{pH} 6.4$, except for lactase (at $\mathrm{pH}$ 5.6). Liberated glucose was determined by enzymatic reactions resulting in increased reduced nicotinamideadenine dinucleotide formation. Units are expressed as $\mu$ moles of glucose formed per min per $g$ protein $(4,12)$.

\section{VIRUS}

Reovirus type 3 was obtained from Dr. Taber (Roswell Park Memorial Institute, Buffalo, N. Y.). The virus pool was prepared in mouse L929 fibroblasts and titered $4.3 \times 10^{\times} \mathrm{PFU} / \mathrm{ml}$ when assayed on the same cell line.

To determine the amount of virus present in small intestinal tissue, small intestines from infected mice were homogenized. Standard virus plaque assays were performed on mouse L929 fibroblasts, and the results were expressed as number of PFU/g of tissue.

\section{STATISTIC $S$}

All results are expressed as mean \pm S.E. Differences in mean values between groups were determined by unpaired Student $t$ test. $P$ 's less than 0.05 were considered significant. 


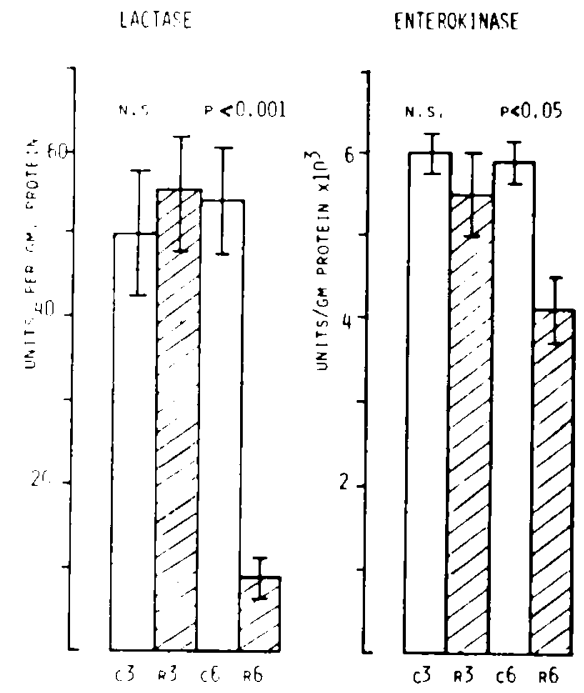

No pathologic changes or enzyme alterations were observed in the infected adult mice compared to the control group.

\section{PATHOLOGY}

Light microscopy revealed no changes in the small intestinal mucosa of the suckling mice sacrificed 3 days after viral infection. However, in the group of mice sacrificed 6 days after infection. the villi were shortened, blunted with lymphangiectatic lesions, and contained a mild mononuclear infiltration in the lamina propria.

\section{INTESTINAL. BRUSH BORDER ACTIVITIES}

Lactase activity (Fig. 1) in the suckling mice 3 days after infection was at the same level as the control group. There was a statistically significant decrease in lactase activity in the group sacrificed 6 days after viral infection as compared to both the control and the group sacrificed 3 days after injection $(P<0.001)$. Enterokinase activity (Fig. 1) was significantly decreased $(P<$ $0.05) 6$ days after infection compared to the age-matched control groups. Maltase activity (Fig. I) was higher in the infected groups compared to controls; however, only in the group sacrificed 6 days after injection was a statistical difference found $(P<0.001)$. Leucine aminopeptidase was significantly higher 6 days after injection of the virus compared to controls $(P<0.05)$. There were no significant differences in the activity of alkaline phosphatase (Fig. 1) between the infected and control mice.

\section{VIROLOGYY}

Reovirus was present in the intestines of suckling mice on both days 3 and 6 . On day 3 , the virus titer was $5.0 \times 10^{4} \mathrm{PFU} / \mathrm{g}$ of tissue, and on day 6 , the virus titer was $4.0 \times 10^{4} \mathrm{PFU} / \mathrm{g}$ of tissue.

\section{DISCUSSION}

In this study, reovirus produced flattening of intestinal villi and concurrent reduction of levels of lactase and enterokinase in suckling mice while having no effect in adult mice. The major pathologic and enzymatic changes were observed 6 days after infection. Significantly lower lactase activity was consistent with the morphologic abnormalities and mucosal injury observed. It is well known that lactase is more sensitive to mucosal injury tha: are other disaccharidases $(10)$, and this is reflected in our result as well. Holmes et al. (6) suggested that lactase acts as a recepto and an uncoating enzyme for rotavirus. The same mechanisn may be hypothesized for reovirus because virologic data verifie reovirus replication in the small intestine. This hypothesis ma also explain the susceptibility of the neonatal but not adult animal to reovirus-like agents because adults normally have low activit: of lactase. Another explanation for the failure to effect changes if adult mice could be the presence of immunity from prior exposurt to the viral agent. Enterokinase activity was also found to bc reduced after the viral infection. These results are similar to the situation observed during intractable diarrhea of infancy (11).

In contrast to what was expected, maltase and leucine amino. peptidase activities in infected suckling mice were higher than ir the control mice. In several species of suckling animals including mice, maltase activity is low in the neonatal period and rise: during the third wk postnatally (1). One possible explanation for our observation is the specific induction of enzymes undergoing development during the time of infection. It was also suggested that the viral invasion of the intestinal mucosa caused villous cell destruction, and as a consequence, the newly generated mucosa is crypt-like in character (8). These new generations of crypt cells may be capable of producing higher levels of maltase and lower levels of lactase activity. Although it is true that the IP inoculation of the reovirus is not an equivalent of the common route of viral infection in infants, it serves as a useful model to demonstrate the effect of viral replication on small intestinal brush border enzymes and histology. Furthermore, studies are needed to determine if these changes in brush border enzymes are relevant to the disease produced by rotavirus in humans.

\section{REFERENCES AND NOTES}

1. Auricchio, S., Rubino. A.. and Murset, (;.: Intestinal glycosidase activities in the human embryo, fetus, and newborn. Pediatrics, o: 944 (1965).

2. Berger, L.. and Rudolph, C. (j.: Alkaline and acid phosphatases. Stand. Methods Clin. Chem. s: $211(1965)$.

3. Bishop. R. F., Davidson. (i. P., Holmes. I. H., et al.: Virus particles in epithelial cells of duodenal mucosa from children with acute non-bacterial gastroenteritis. L.ancet. ?: 1281 (1973).

4. Dahlquist. A.: Method for assay of intestinal disaccharidases. Anal. Biochem. 7 $18(1964)$.

5. Hadorn, B., Tarlow, M. J., L.loyd. J. K., et al.: Intestinal enterokinase deficiency Lancet. I: 812 (1969).

6. Holmes. I. H., Rodger. S. M., Schnagel, R. D.. ef al: Is lactase the receptor and 
uncoating ensyme tor intantile enteritis (ROTA) viruses'? Lancet. $I$ : $13 \times 7$ 114761

Wolmes I H Ruck, B J. Bishop, R. F.. et al: Infantile enteritis virus: morphogenesis and morphology. J. Virol., In: 937 (1975).

serzner. B.. Kelly. M. H.. Gall, D. G.. et al:: Transmissible gastroenteritis: sodium transport and the intestinal epithelium during the course of viral enteritis. Gastroenterology, 72: 457 (1977).

Kerıner. B.. and Mc( lung. H. J.: Viral gastroenteritis. In: E. Lebenthal: Digestive Diseases in (hildren. pp. 333-350) (Cirune \& Stratton. New York. 1978). ehenthal, E.: Small intestinal disaccharidase deticiencies. Pediatr. ('lin. N. Am.. 2(): $757(1975)$

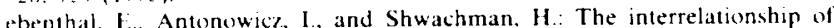
enterokinase and trypsin activities in intractable diarrhea of infancy, celiac discase, and intravenous alimentation. Pediatrics, 5 h: 585 (1975).

ilein. $M$ W : b-Cilucose determinations with hexokinase and glucose- 6 -phosphate dehydrogenase. In: H. V. Bergmeyer: Methods of Enzymatic Analysis. p. 117 (Academic Press, Inc.. New York. 1965)
13. Suzuki. H. and Konno, T.: Reovirus-like particles in jejunal mucosa of a Japanese infant with acute infectious non-bacterial gastroenteritis. Tohoku $\mathrm{J}$. Exp. Med., 115: $199(1975)$

14. Sias (i. A kinetic photometric method for serum leucine aminopeptidase. Am J. (lin. Pathol., 47: 607 (1967)

15. Wyatt. R. ( $;.$. and Kapikain, A. Z.: Viral agents associated with acute gastroenteritis in humans. Am. J. (lin. Nutr., 30: 1857 (1977).

16. Dr. David Branski is a Postdoctoral Fellow from Bikur Cholim Hospital, Jeru salem. Israel.

17. The authors thank Dr. John Fisher for his assistance in the morphological studies. Bridget Krant/ and Ok Kim for the skillful technical assistance, and Mary Lou Jegierski for her secretarial assistance.

18. Requests for reprints should be addressed to: Emanuel Lebenthal. M.D.. Division of (jastroenterology and Nutrition. (hildren's Hospital. 219 Bryant Street. Buffalo. New York 14222 (USA)

19. Received for publication May 22. 1979

20. Accepted for publication August 30, 1979 